\title{
Functional and biochemical interactions of Wnts with FrzA, a secreted Wnt antagonist
}

\section{Citation}

Xu, Qihong, Patricia A. D'Amore, Sergei Y. Sokol. 1998. Functional and biochemical interactions of Wnts with FrzA, a secreted Wnt antagonist. Development 125: 4767-4776

\section{Permanent link}

http://nrs.harvard.edu/urn-3:HUL.InstRepos:36305726

\section{Terms of Use}

This article was downloaded from Harvard University's DASH repository, and is made available under the terms and conditions applicable to Other Posted Material, as set forth at http:// nrs.harvard.edu/urn-3:HUL.InstRepos:dash.current.terms-of-use\#LAA

\section{Share Your Story}

The Harvard community has made this article openly available.

Please share how this access benefits you. Submit a story.

\section{Accessibility}




\title{
Functional and biochemical interactions of Wnts with FrzA, a secreted Wnt
}

\section{antagonist}

\author{
Qihong Xu1 ${ }^{1}$, Patricia A. D'Amore ${ }^{1}$ and Sergei Y. Sokol2,* \\ Departments of Pathology ${ }^{1}$ and Microbiology and Molecular Genetics ${ }^{2}$, Harvard Medical School and Laboratory for Surgical \\ Research, Children's Hospital ${ }^{1}$, and Molecular Medicine Unit, Beth Israel Deaconess Medical Center ${ }^{2}$, 330 Brookline Ave., Boston, \\ MA 02215, USA \\ *Author for correspondence (e-mail: ssokol@bidmc.harvard.edu)
}

Accepted 6 September; published on WWW 9 November 1998

\section{SUMMARY}

Wnts are highly conserved developmental regulators that mediate inductive signaling between neighboring cells and participate in the determination of embryonic axes. Frizzled proteins constitute a large family of putative transmembrane receptors for Wnt signals. FrzA is a novel protein that shares sequence similarity with the extracellular domain of Frizzled. The Xenopus homologue of FrzA is dynamically regulated during early development. At the neurula stages, XfrzA mRNA is abundant in the somitic mesoderm, but later becomes strongly expressed in developing heart, neural crest derivatives, endoderm, otic vesicle and other sites of organogenesis. To evaluate possible biological functions of FrzA, we analyzed its effect on early Xenopus development. Microinjection of bovine or Xenopus FrzA mRNA into dorsal blastomeres resulted in a shortened body axis, suggesting a block of convergent extension movements. Consistent with this possibility, FrzA blocked elongation of ectodermal explants in response to activin, a potent mesoderm-inducing factor. FrzA inhibited induction of secondary axes by Xwnt8 and human Wnt2, but not by Xdsh, supporting the idea that FrzA interferes with Wnt signaling. Furthermore, FrzA suppressed Wnt-dependent activation of the early response genes in ectodermal explants and in the marginal zone. Finally, immunoprecipitation experiments demonstrate that FrzA binds to the soluble Wingless protein in cell culture supernatants in vitro. Our results indicate that FrzA is a naturally occurring secreted antagonist of Wnt signaling.

Key words: Frizzled, Dishevelled, Mesoderm, Dorsoventral axis, Morphogenetic movement, Activin, Xenopus

\section{INTRODUCTION}

Determination of cell fates during development often depends on a cascade of inductive interactions. Reciprocal signaling between neighboring cells leads to the establishment of embryonic polarity and generates body patterns. One class of signaling molecules that are active throughout animal development includes Wnt family members (Parr and McMahon, 1994; Cadigan and Nusse, 1997). Wnt genes are related to the Wnt1-proto-oncogene and to Drosophila wingless $(w g)$, and are expressed in a variety of tissues and organs. Different Wnt gene homologues are required for many developmental processes, including segmentation in Drosophila (reviewed by Perrimon, 1994), endoderm development in Caenorhabditis elegans (Rocheleau et al., 1997; Thorpe et al., 1997), limb polarity (Yang and Niswander, 1995; Riddle et al., 1995; Parr and McMahon, 1995), and kidney morphogenesis (Stark et al., 1994; Herzlinger et al., 1994). In addition, several Wnts are essential for proper development of brain and spinal cord (reviewed by Parr and McMahon, 1994). Wnt signaling may also be involved in the establishment of dorsoventral and anteroposterior axes (Sokol et al., 1991; Smith and Harland, 1991; McGrew et al., 1995; Itoh et al., 1995; Itoh and Sokol, 1997; Fredeiu et al., 1997) and in the control of morphogenetic movements during gastrulation in Xenopus (Moon et al., 1993; Sokol, 1996).

Several components of the Wnt/Wg signal transduction pathway have been identified in Drosophila. Dishevelled (Dsh) and Armadillo (Arm) proteins are required for the response of Drosophila cells to $\mathrm{Wg}$, whereas Shaggy/GSK3 kinase antagonizes the effect of Wg (Perrimon, 1994). Dsh is phosphorylated in response to Wg (Yanagawa et al., 1995) and transduces the Wg signal upstream of Arm. The same signaling pathway appears to be conserved in vertebrates, because Xenopus homologues of Dsh (Xdsh) and Arm ( $\beta$-catenin and plakoglobin) and dominant negative forms of GSK3 (a homologue of shaggy), all mimic the ability of Wnts to induce a secondary body axis in Xenopus embryos (Sokol et al., 1995; Rothbacher et al., 1995; Funayama et al., 1995; Karnovsky and Klymkowsky, 1995; Dominguez et al., 1995; He et al., 1995; Pierce and Kimelman, 1995). Axin, a novel cytoplasmic product of the mouse Fused gene, functions as a negative regulator of the Wnt pathway (Zeng et al., 1997). Depletion of maternal $\beta$-catenin or overexpression of cadherins in Xenopus 
oocytes and embryos abolishes the response to a Wnt signal (Heasman et al., 1994). Consistent with a position for Xdsh upstream of $\beta$-catenin, interference with the function of Xdsh inhibits the axis-inducing ability of Xwnt8, but not that of $\beta$ catenin (Sokol, 1996). Recent studies have revealed that $\beta$ catenin, associated with HMG-box-containing LEF-1-related transcription factors, translocates into the nucleus where it affects gene expression (Molenaar et al., 1996; Behrens et al., 1996; Huber et al., 1996; see Cadigan and Nusse, 1997, for a review). A similar transcription factor encoded by the fly gene pangolin, or $d T C F$, is required for $\mathrm{Wg}$ signaling in Drosophila (Brunner et al., 1997; van de Wetering et al., 1997) .

Wnt signal transduction may also involve Frizzled proteins, a large family of putative receptors, which consist of an extracellular cysteine-rich domain (CRD), seven transmembrane domains, and a short cytoplasmic tail (Vinson et al., 1989; Chan et al., 1992; Wang et al., 1996; reviewed by Perrimon, 1996). Frizzled was initially identified as a Drosophila mutation that interferes with the polarized pattern of hair growth on the fly wing, often referred to as tissue polarity (reviewed by Adler, 1992). The tissue polarity is disrupted in both frizzled and $d s h$ mutants, but not in $w g$ mutants (Adler, 1992). Despite the lack of genetic linkage between $w g$ and frizzled, recent studies suggest that Frizzled proteins may function as receptors for Wnts (Bhanot et al., 1996). Transfection of $D f z-2$, a novel Drosophila frizzled homologue, into a non-responsive S2 cell line confers responsiveness to $\mathrm{Wg}$ and promotes $\mathrm{Wg}$ binding to the cell surface (Bhanot et al., 1996). Synergistic interactions between specific Wnt and Frizzled proteins were observed upon their co-injection in Xenopus embryos (He et al., 1997; Yang-Snyder et al., 1996). Together, these experiments suggest that the Frizzled proteins may function as receptors for Wnt ligands. The existence of many different Wnt and Frizzled genes, expressed during development in distinct spatial and temporal patterns, raises the question of how Wnt signaling is regulated in vivo.

In addition to Frizzled transmembrane receptors, recent studies have identified several secreted polypeptides that are related to the Frizzled extracellular domain but lack the transmembrane and intracellular domains of Frizzled (Hoang et al., 1996; Shirozu et al., 1996; Wang et al., 1996, 1997a; Leyns et al., 1997; Mayr et al., 1997; Rattner et al., 1997; Finch et al., 1997; Salic et al., 1997; Melkonyan et al., 1997). Some of these polypeptides have been shown to antagonize Wnt signaling. We have previously isolated a bovine cDNA, encoding a protein that belongs to the same family (Duplaa, C., Xu, Q. and D'Amore, P. A., unpublished). This protein, named FrzA (Frizzled in Aorta), is secreted and is abundant in the aortic endothelium, brain and retinal neurons, lung and kidney epithelium, and cardiac myocytes. We have now isolated a Xenopus homologue of FrzA and show that it is dynamically regulated during development. To evaluate the possible role of FrzA in modulating the Wnt pathway in vivo, we overexpressed both Xenopus and bovine FrzA in the frog embryos. Wnts are known to elicit specific developmental abnormalities in Xenopus, making this system a fast and convenient model for the analysis of the Wnt pathway. To determine whether FrzA functions as a soluble Wnt-binding protein, we tested whether FrzA is capable of in vitro interactions with Wg, a Drosophila Wnt-1 homologue. Our data indicate that FrzA associates with Wnts in vitro and antagonizes Wnt signaling in the embryo.

\section{MATERIALS AND METHODS}

\section{Eggs and embryos}

Eggs were obtained by injecting Xenopus laevis females with 700 units of human chorionic gonadotropin. In vitro fertilization and embryo culture were carried out in $0.1 \times$ MMR $(1 \times \mathrm{MMR}=100 \mathrm{mM}$ $\mathrm{NaCl}, 2 \mathrm{mM} \mathrm{KCl}, 1 \mathrm{mM} \mathrm{MgSO}$, $2 \mathrm{mM} \mathrm{CaCl}_{2}, 5 \mathrm{mM}$ Hepes, $\mathrm{pH}$ 7.6, $0.1 \mathrm{mM}$ EDTA) as described (Newport and Kirschner, 1982). Embryonic stages were determined according to Nieuwkoop and Faber (1967).

\section{DNA constructs, RNA synthesis, microinjections and explant culture}

XfrzA cDNA was isolated by screening a Xenopus stage $17 \lambda$ gt10 cDNA library at low stringency with ${ }^{32} \mathrm{P}$-labeled SacII-ApaI DNA fragment of bovine FrzA (Duplaa et al., unpublished; GenBank accession number U85945) as described (Sambrook et al., 1989). A $1.5 \mathrm{~kb}$ insert from the positive phage, which contained a large open reading frame, was subcloned into pBSKS and sequenced in both directions. The XfrzA sequence has been submitted to the GenBank (accession number AF049908).

Capped synthetic RNAs were generated as described (Krieg and Melton, 1984) by in vitro transcription of plasmids containing the entire coding sequence of Xenopus or bovine FrzA in pXT7 (Dominguez et al., 1995), XfrzB (Leyns et al., 1997), Xdsh (Sokol et al., 1995), human Wnt2 (a gift of A. McMahon), Xwnt5a (Moon et al., 1993) and Xwnt8 (Christian et al., 1991), using Megascript RNA transcription system (Ambion). In some experiments Xwnt8-pCS2 plasmid (a gift of R. Moon) was used for injections.

A myc-tagged form of bovine FrzA was generated by PCR with the following primers: (frzU: 5'-TCTGCCTGGACCGGCCCATCTA-3' and frzD: 5'-AGGATCCTCGAGCTTGAAGACCGACTG-3'). The full coding sequence of FrzA was subcloned into $\mathrm{pJ} 3 \Omega \mathrm{M}$ vector that encodes a myc-epitope (Patriotis et al., 1994) for transfection of COS7 cells. HindIII and BglII-digested myc-FrzA cDNA was subcloned into pXT7 for RNA microinjections. For mRNA and plasmid DNA injections, embryos were transferred to $3 \%$ Ficoll in $0.5 \times$ MMR and injected as specified in different experiments with $10 \mathrm{nl}$ of RNA or DNA solution in RNase-free water.

Ectodermal explants (animal caps), constituting about one fifth of the size of the embryo, were excised at the midblastula stage (stage 8-8.5) and cultured in 0.7× MMR as described (Sokol, 1993). Total RNA was extracted from cultured explants for northern analysis, when control embryos reached stage 10.5-11.

\section{Whole-mount in situ hybridization and sectioning}

An antisense RNA probe was synthesized by in vitro transcription of full-length XfrzA cDNA in the presence of digoxigenin-UTP. Wholemount in situ hybridization was performed as described (Harland, 1991). After in situ hybridization, the embryos were fixed in MEMFA (Harland, 1991), rehydrated through a gradated ethanol-xylene series, embedded in Paraplast, and sectioned at $12 \mu \mathrm{m}$.

\section{Preparation of soluble $\mathbf{W g}$ and FrzA proteins}

S2-Wg Drosophila cells, stably transfected with the plasmid containing $w g$ cDNA under the control of a heat shock promoter, were used as a source of $\mathrm{Wg}$ protein (Van Leeuwen et al., 1994). For Wg protein preparation, $\mathrm{S} 2-\mathrm{Wg}$ cells were heat-shocked for 45 minutes at $37^{\circ} \mathrm{C}$, cells were allowed to recover in the serum-containing medium for 35 minutes at room temperature, the medium was replaced with the serum-free M3 medium and conditioned medium was collected after 4 hours at room temperature as described (Van Leeuwen et al., 1994). 
For bovine FrzA production, exponentially growing COS-7 cells were transfected with $20 \mu \mathrm{g}$ of $\mathrm{pJ} 3 \Omega \mathrm{M}$-FrzA or pJ3$\Omega \mathrm{M}$ DNA using the calcium phosphate technique (Graham and Van Der Eb, 1973). The conditioned serum-free DMEM medium containing FrzA was collected after 3 days of culture. Conditioned media containing FrzA and $\mathrm{Wg}$ proteins were concentrated approximately 20 times using Centricon-30 (Amicon).

\section{Immunoprecipitation and western blot analysis}

Equal volume amounts of conditioned media containing soluble mycFrzA (or control supernatant from pJ3 $\Omega$ M-transfected COS-7 cells) and $\mathrm{Wg}$ protein (or S2-cell-conditioned medium) were mixed and incubated for 10 minutes at room temperature. Myc-specific 9E10 hybridoma supernatant $(15 \mu \mathrm{l})$ (Evan et al., 1985) was added and incubated overnight at $4^{\circ} \mathrm{C}$. Immune complexes were immobilized on protein A Sepharose and washed three times with PBS. Washed beads and one fifth volume of concentrated conditioned medium before and after immunoprecipitation were subjected to SDS-polyacrylamide gel electrophoresis. Separated proteins were blotted onto Immobilon $\mathrm{P}$ membrane and probed with rabbit antibodies against $\mathrm{Wg}$ (a gift of $\mathrm{R}$. Nusse) followed by goat anti-rabbit IgG secondary antibodies conjugated with horseradish peroxidase (Jackson Labs). The same membrane was stripped in $7 \mathrm{M}$ guanidine- $\mathrm{HCl}, 50 \mathrm{mM}$ Tris- $\mathrm{HCl}, \mathrm{pH}$ 8.0, $20 \mathrm{mM}$ dithiotreitol, $2 \mathrm{mM}$ EDTA and re-probed with 9E10 antibodies followed by goat anti-mouse secondary antibodies coupled with peroxidase. The protein bands were visualized using enhanced chemiluminescence.
1997), but not to other members of the Frizzled family. For instance, XfrzA and XfrzB have 23\% similarity at the amino acid level whereas XfrzA and FRP1 have $66 \%$ similarity. The comparison between XfrzA and other FrzB/FRP genes is shown in Fig. 1.

The expression of XfrzA during development was studied by northern blot analysis (Fig. 2). XfrzA probe detected a single mRNA species with a size of approximately $2 \mathrm{~kb}$. The maternal contribution to XfrzA expression is extremely low to negligible at the blastula and early gastrula stages. The zygotic signal was significant only by the end of gastrulation and was well pronounced at the neurula, tailbud and tadpole stages. There was a reproducible decline in XfrzA mRNA levels at stage 22 , which is consistent with in situ hybridization data.

Whole-mount in situ hybridization analysis revealed spatial aspects of XfrzA expression. XfrzA transcripts are not detected in gastrulae (Fig. 3A), and the transcripts are first seen in somitic mesoderm at the neurula stage (Fig. 3B,C,G). At the tailbud stages, XfrzA is found in neural crest cells, heart, otic vesicle, pronephros, endoderm and the ventral part of the neural tube at the hindbrain level (Fig. 3E,H-M). Interestingly, heart-specific expression of XfrzA was confined to the myocardium with little or no staining in the pericardium or endocardium areas (Fig. 3I,K,L).

\section{Northern blot analysis}

Total RNA was prepared from explants and embryos as described (Itoh et al., 1995). For northern analysis, RNA was separated in a $1 \%$ formaldehyde-agarose gel using standard techniques (Sambrook et al., 1989). RNA from ten animal caps or two embryos was loaded per lane unless noted otherwise. RNA was transferred to a GeneScreen nylon membrane (Dupont) with 20x SSPE and was sequentially hybridized with radiolabeled DNA or RNA probes (Sambrook et al., 1989). Antisense RNA probes were prepared by in vitro transcription (Krieg and Melton, 1984) from plasmids containing XfrzA, Xlim-1 (Taira et al., 1992), Otx2 (Pannese et al., 1995), chordin (Sasai et al., 1994), cerberus (Bouwmeester et al., 1996), PV1 (Ault et al., 1996), XMyoD (Hopwood et al., 1989), goosecoid (Blumberg et al., 1991) and fibronectin (Krieg and Melton, 1985), using $\left[\alpha_{-}{ }^{32} \mathrm{P}\right] \mathrm{UTP}$ and SP6, T3 or T7 RNA polymerase. DNA probes for Xbra (Smith et al., 1991), Xnr3 (Smith et al., 1995) were radiolabeled with $\left[\alpha_{-}{ }^{32} \mathrm{P}\right] \mathrm{dCTP}$ by Klenow enzyme using random hexamer primers (Sambrook et al., 1989). After hybridization, the probe was stripped by boiling in distilled water. The same membrane was used for hybridization with all probes.

\section{RESULTS}

\section{XfrzA is dynamically regulated during development}

To isolate the Xenopus homologue of FrzA, we probed a Xenopus neurula cDNA library at low stringency with bovine FrzA cDNA. The $1.5 \mathrm{~kb}$ insert from the positive phage contained an open reading frame encoding a protein highly similar to bovine FrzA and human FRP1 (Finch et al.,

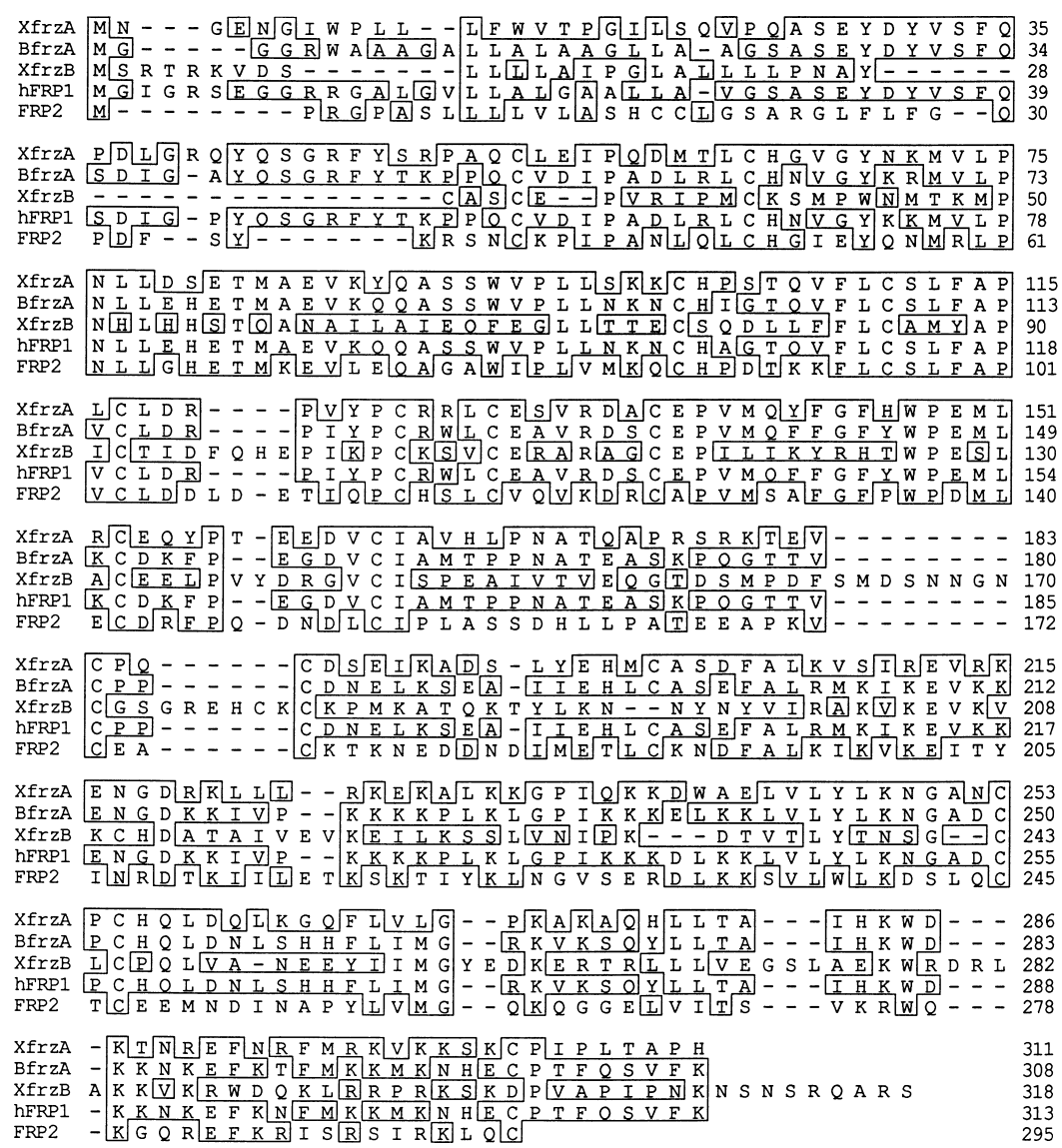

Fig. 1. Comparison of amino acid sequences of XfrzA and other Frizzled CRD homologues. The amino acid residues that are identical between the proteins are boxed. Numbers indicate positions of the last amino acid. 


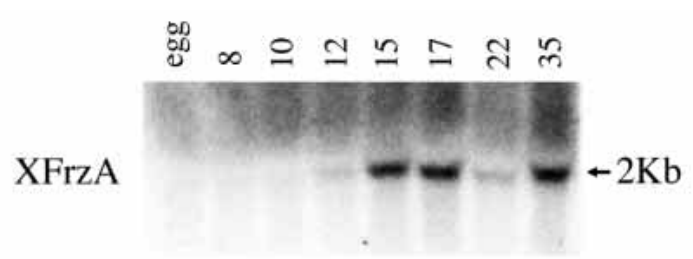

FN

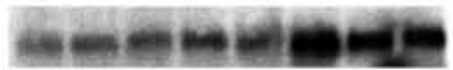

Fig. 2. Expression of XfrzA during Xenopus development. Total RNA was extracted from different stages of Xenopus embryos as indicated, and probed with [ $\left.\alpha-{ }^{32} \mathrm{P}\right] \mathrm{UTP}-$ labeled antisense XfrzA RNA. Two embryo equivalents were loaded per lane, except that only one embryo equivalent was loaded for stage 22 , and $3 / 4$ equivalents for stage 35. Fibronectin (FN) was used as a loading control.

\section{The effect of FrzA mRNA on early development}

Since FrzA is similar to the extracellular domain of Frizzled, it may modulate Wnt function in vivo. To analyze the potential biological role of FrzA, we overexpressed FrzA in Xenopus embryos by microinjection of its mRNA. Ventral injections of 0.5-1 ng of FrzA mRNA in four-cell embryos had no significant effect on the overall morphology of developing tadpoles (Fig. 4A). Occasionally, the tail of injected embryos was slightly bent. We suspect that in these cases the injected mRNA may have been mislocalized to a lateral position. Bovine or Xenopus FrzA mRNA did not induce secondary axes on the ventral side, indicating that neither stimulates the Wnt signal transduction pathway.

Dorsal injections of $1 \mathrm{ng}$ of bovine FrzA mRNA reproducibly led to dorsally curved embryos with severely truncated posterior tissues (Fig. 4B). Head development was not significantly affected in these embryos. The lack of axis extension was seen in a majority of injected embryos and was observed using both myc-tagged and non-tagged variants of FrzA. This phenotype is very similar to inhibition of axis extension that occurs in embryos when Wnt signaling is blocked by overexpression of Xdd1, a dominant negative form of Xdsh (Sokol, 1996). Microinjections of XfrzA resulted in a similar phenotype (data not shown), whereas control dorsal injections of the same dose of EF-1a mRNA did not alter normal development. These observations suggested that FrzA is a naturally occuring inhibitor of Wnt signaling.

Fig. 3. Localization of XfrzA mRNA in Xenopus embryos by whole-mount in situ hybridization (A-F) and sections (G-M). XfrzA antisense probe was used in A-C and $\mathrm{E}$; control En-2 antisense probe was used in $\mathrm{D}$ and $\mathrm{F}$. (A) Stage 10.5; (B-D,G) stage 17; B is dorsal and C is lateral view. (E,F,H,J,K,M) Stage 29-30. (I,L) Stage 35. (B-F) Anterior is to the left. s, somitic tissue; ov, otic vesicle; nc, neural crest cells; nt, neural tube; not, notochord; bv, brain ventricle; nr, neural retina; pn, pronephros; hb, hindbrain; mc, myocardium; pc, pericardium; ec, endocardium; h, heart anlage; en, endoderm.
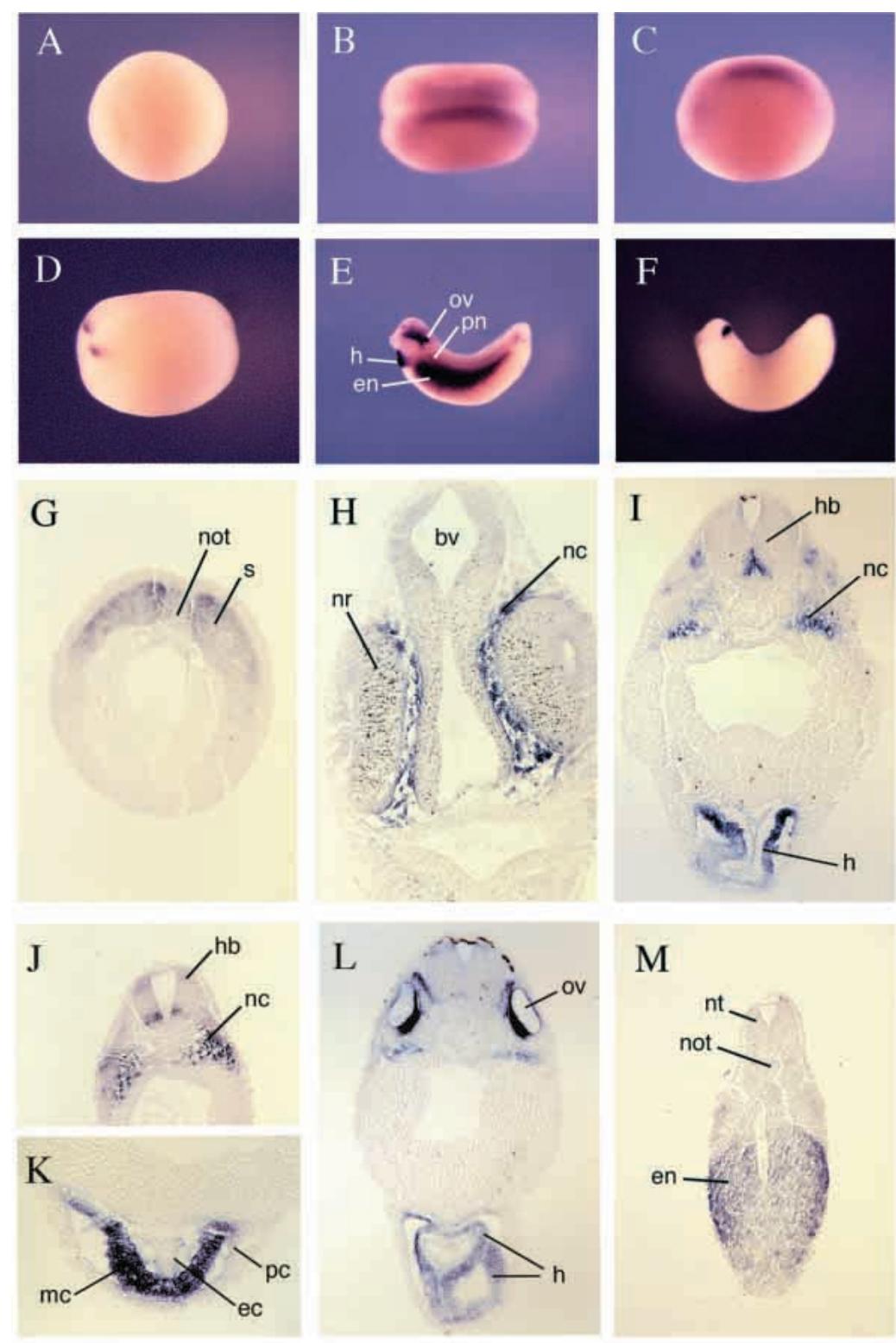

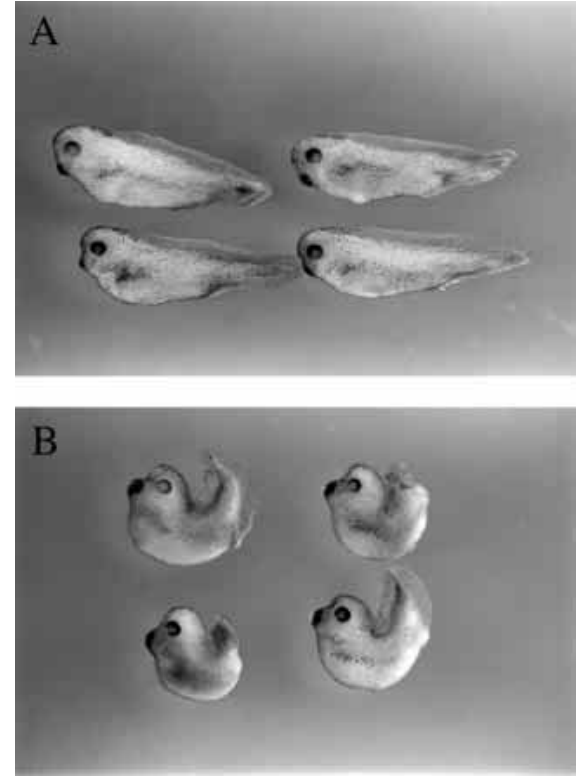

Fig. 4. The effect of FrzA overexpression on normal development. FrzA mRNA (1 ng) was injected into two ventral (A) or dorsal (B) blastomeres of the four-cell embryos and their morphology was assessed after 48 hours of culture at room temperature. The morphology of embryos that were injected dorsally with $1 \mathrm{ng}$ of EF1 mRNA was similar to A.

\section{FrzA blocks axis-inducing activities of Xwnt8, but not that of Xenopus Dishevelled}

To test whether FrzA functions in the embryo by preventing the interactions of Wnt ligands with the proper receptor, we evaluated whether it suppresses the axis-inducing activity of Xwnt8. In addition, if FrzA acts outside of the cell, then we would expect that it should not interfere with intracellular mediators of Wnt signaling such as Dishevelled (Dsh). Both Xwnt 8 and Xdsh mRNAs are known to induce a complete secondary axis upon microinjection in a ventral blastomere (Sokol et al., 1991, 1995). Co-injection of Xwnt8 mRNA and bovine or Xenopus FrzA mRNA in a single ventral blastomere resulted in a complete inhibition of secondary axis induction by Xwnt8 (Table 1, Fig. 6A,B). In contrast, FrzA mRNA failed to inhibit axis induction by Xdsh mRNA (Table 1, Fig. 6C, D), a result that is consistent with the position of Dsh downstream of Frizzled in the Wnt signal transduction pathway. Even at the
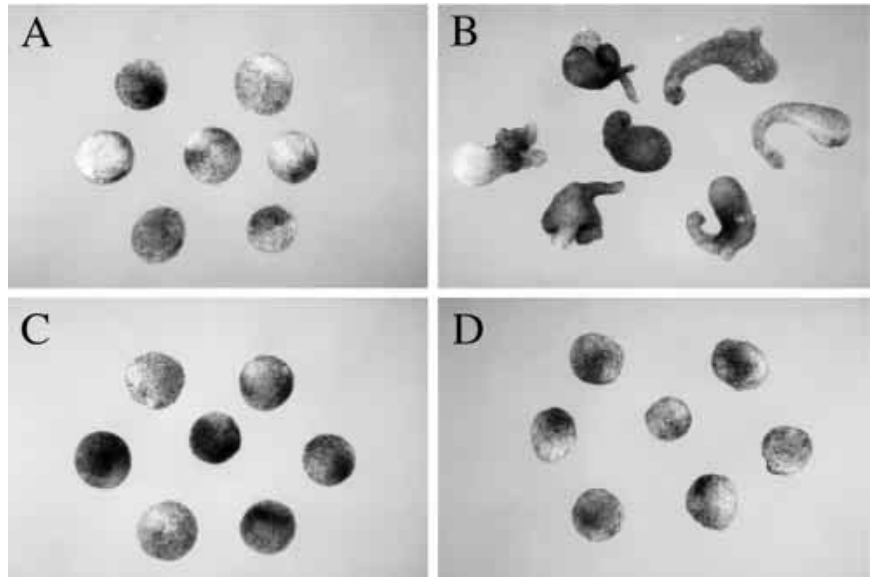

Fig. 5. FrzA inhibits morphogenetic movements of ectodermal explants stimulated with activin. Both blastomeres of two-cell embryos were injected into the animal hemisphere with $1 \mathrm{ng}$ of FrzA mRNA. Animal pole explants were excised from uninjected controls $(\mathrm{A}, \mathrm{B})$ or microinjected embryos $(\mathrm{C}, \mathrm{D})$ at the midblastula stage. The explants were cultured in $0.7 \times \mathrm{MMR}$ in the absence $(\mathrm{A}, \mathrm{C})$ or in the presence of $2 \mathrm{ng} / \mathrm{ml}$ of human activin $\mathrm{A}(\mathrm{B}, \mathrm{D})$ until the control embryos reached stage 17 .

twofold lower doses of Xdsh mRNA, at which only partial axes are induced (Sokol et al., 1995), we failed to detect significant inhibition by FrzA (data not shown).

\section{The effects of FrzA on early marginal zone markers}

Morphological observations were further confirmed by the molecular data showing that Xwnt8-dependent activation of two marginal zone markers $\mathrm{Xnr}-3$ and chordin was inhibited by FrzA in ectodermal explants (Fig. 7A). Expression of Otx2 was not blocked to the same degree, suggesting that it may be activated by a different mechanism. On its own, FrzA did not stimulate any tested marginal zone markers in animal cap explants (Fig. 7A). In contrast, GSK3, another inhibitor of the Wnt pathway, upregulates Otx2 expression in animal caps (Itoh et al., 1995). These observations indicate that the pathway is likely to branch out or to cross-talk with different signal transduction pathways.

We then compared the effects of FrzA and FrzB mRNAs on the expression of several marginal zone markers. Wnt2 expression in ventral vegetal cells leads to induction of Chd,

Table 1. The effects of FrzA mRNA on axis-inducing ability of Xwnt8, Wnt2 and Xdsh mRNAs

\begin{tabular}{|c|c|c|c|c|c|}
\hline $\begin{array}{l}\text { Injected } \\
\text { mRNA }\end{array}$ & $\begin{array}{l}\text { Total number of } \\
\text { embryos injected }\end{array}$ & $\begin{array}{c}\text { Embryos with } \\
\text { complete second axis }\end{array}$ & $\begin{array}{c}\text { Embryos with } \\
\text { partial second axis }\end{array}$ & Single axis & Other \\
\hline Xwnt8 & 75 & $69(91 \%)$ & 2 & 4 & - \\
\hline Xwnt8+FrzA & 84 & 0 & 10 & 74 & - \\
\hline Xdsh & 52 & $39(75 \%)$ & 8 & 5 & - \\
\hline Xdsh+FrzA & 57 & $47(75 \%)$ & 6 & 4 & - \\
\hline Wnt2 & 92 & $55(60 \%)$ & 22 & 4 & 9 \\
\hline Wnt2+FrzA & 72 & 0 & 0 & 56 & 16 \\
\hline
\end{tabular}

Synthetic mRNAs were injected with 1 pg of Xwnt8 mRNA, 40 pg of Wnt 2 mRNA, 1 ng of Xdsh mRNA or a combination of these with 0.5-1.0 ng of FrzA mRNA, into a single ventrovegetal blastomere of four-cell stage embryos and allowed to develop to stage 35 . Induced secondary axes were considered complete when ectopic eyes and cement glands were apparent at tadpole stages, or partial when ectopic neural tube lacked the anteriormost head derivatives.

The data represent five independent experiments.

Other defects included early cleavage arrest, failure of the yolk plug closure and kinked tail. 


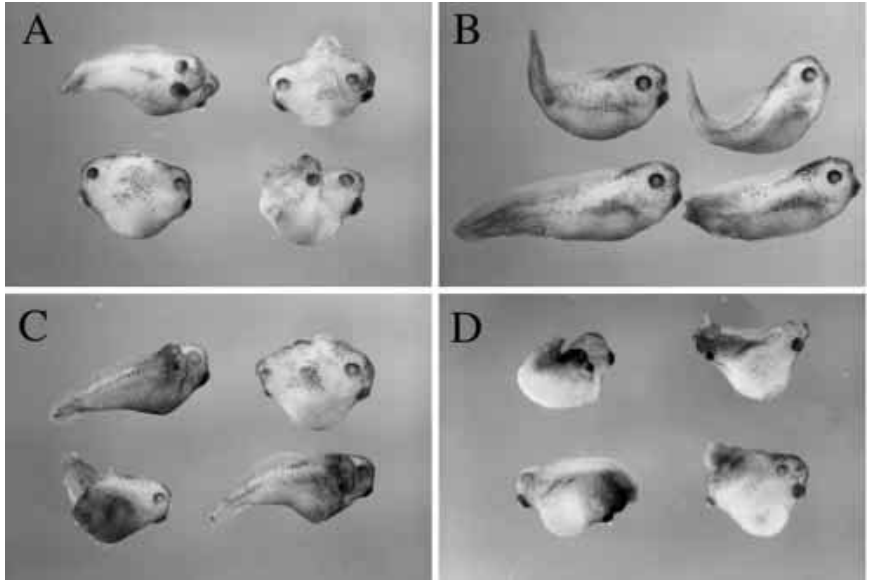

Fig. 6. FrzA blocks induction of secondary axes by Xwnt8, but not by $\mathrm{Xdsh}$. Embryos were injected into a single ventrovegetal blastomere at the 4- to 8-cell stage with $1.0 \mathrm{pg}$ of Xwnt8 mRNA (A), $1.0 \mathrm{pg}$ of Xwnt8 mRNA plus $0.5-1.0 \mathrm{ng}$ of FrzA mRNA (B), $1.0 \mathrm{ng}$ of Xdsh mRNA (C), 1.0 ng of Xdsh mRNA plus 0.5-1.0 ng of FrzA mRNA (D). Secondary axes were scored as described in Table 1 legend.

Otx2, Cer and XmyoD (Fig. 7B). This induction was blocked by injection of Wnt2 mRNA with FrzA or FrzB, consistent with the effect of XfrzA on animal cap explants.

Injection of FrzA RNA into the dorsal margin led to suppression of XmyoD, and a weak increase in expression of Otx2 (Fig. 7B, XFA/d, and data not shown). Both XfrzB and a dominant negative Wnt construct have been reported to block XmyoD expression (Leyns et al., 1997; Wang et al., 1997a; Hoppler et al., 1996). While XfrzB was shown to cause an increase in chordin (Leyns et al., 1997) and to induce a partial secondary axis (Wang et al., 1997a), we detected no other significant changes of dorsal markers in embryos overexpressing XfrzA (Fig. 7B and data not shown). Together, these results argue that FrzA is a direct inhibitor of Wnt signaling and may block the accessibility of Wnts to their endogenous receptors. Our findings lend further support to participation of some Wnt ligand(s) in both myogenesis and head development, since MyoD and Otx2 are known to be involved in these processes.

\section{Selectivity of FrzA-Wnt interactions}

To determine if FrzA can modulate the function of other Wnt products, we tested whether it interferes with the activity of Wnt2. When mRNA encoding human Wnt2 (a gift of A. McMahon) was injected in a ventral blastomere, it triggered the formation of complete secondary axes (Table 1), similar to those induced by Xwnt8, Wnt1 (Sokol et al., 1991) and Wnt3a (Wolda and Moon, 1993). Coinjection of bovine FrzA mRNA inhibited this axis-inducing activity of human Wnt2, indicating that FrzA can interact with both Wnt ligands (Table 1). However, we did not detect a significant effect of FrzA on activity of Xwnt8 DNA (Christian and Moon, 1993) or BMP4 RNA (Dale et al., 1992; Sasai et al., 1995), which are both known to ventralize early embryos. For Xwnt8 DNA experiments, 10, 20 and 40 pg of Xwnt8-pCS2 plasmid were injected into both dorsal blastomeres of four-cell stage embryos in the absence or presence of 0.1- 0.4 ng of XfrzA
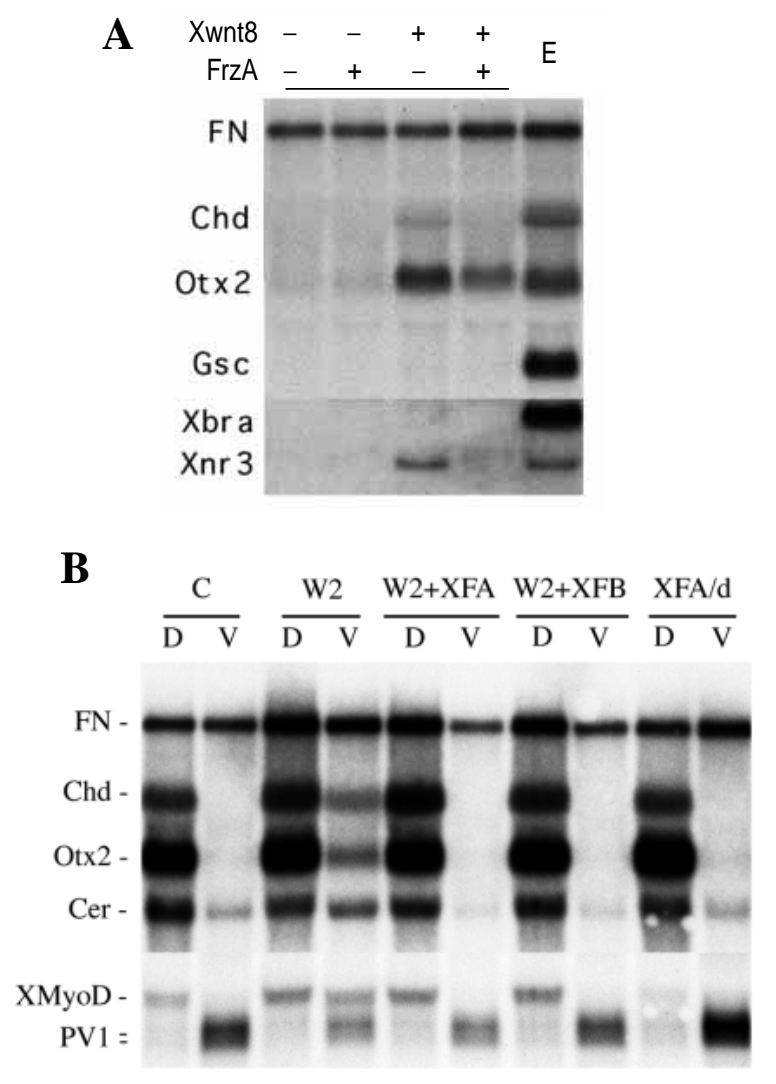

Fig. 7. The effect of FrzA on early marginal zone marker expression. (A) FrzA inhibits Xwnt8-dependent activation of dorsal marginal zone markers in animal pole explants. Two-cell embryos were injected into both blastomeres with 5 pg of Xwnt8 RNA, 1-2 ng of bovine FrzA RNA, or with both RNAs as indicated. Animal pole explants were isolated at the midblastula stage and cultured until the control embryos reached stage 10.5. E, control embryos.

(B) Analysis of marginal zone markers in injected embryos. Embryos were injected with RNA in two ventral vegetal blastomeres as indicated, except in two right lanes (XFA/d; two dorsal injections). W2, human Wnt2 RNA; XFA, XfrzA RNA; XFB, XfrzB RNA. Dorsal (D) and ventral (V) halves were dissected at stage $10^{+}$and cultured until the controls reached stage 12.5. Total RNA was prepared at stage 10.5 (A) or stage 12.5 (B) for northern analysis. Xnr-3, Otx2, goosecoid (Gsc), chordin (Chd) and cerberus (Cer) are organizer markers; XmyoD, early somitic marker; PV1, ventrolateral marginal zone marker. Xbra is a general mesodermal marker. RNA isolated from ten animal cap explants, four marginal zone halves, or two embryos was loaded in each lane. Fibronectin was probed as a control for loading.

RNA. At 40 pg, Xwnt8 DNA strongly inhibited anterior brain development, whereas $10 \mathrm{pg}$ only caused a marginal effect. Although XfrzA RNA had a pronounced effect on convergent extension movements, it failed to restore forebrain development at any dose of injected plasmid.

A distinct group of Wnts, including Xwnt5a, Xwnt11 and Xwnt4, have developmental effects that differ from the axisinducing activity of Xwnt8 (Moon et al., 1993; Du et al., 1995). These Wnts fail to induce a complete secondary axis, but inhibit morphogenetic movements in the embryo. To determine whether FrzA exhibits any selectivity with respect to its interactions with Wnts, we co-injected different amounts of 
Xwnt5a mRNA and $1 \mathrm{ng}$ of FrzA mRNA into the dorsal marginal region of four-cell embryos. Overexpression of Xwnt5a suppressed morphogenetic movements in 48 out of 62 injected embryos as described previously (Moon et al., 1993). The phenotype resulting from disrupted morphogenetic movements is not easily quantified, and we failed to detect a significant modulation of the Xwnt5a activity by FrzA (axis extension was inhibited in 67 out of 71 injected embryos). These experiments suggest that FrzA may interact with only a subset of Wnt products.

\section{FrzA is actively secreted and associates with $\mathrm{Wg}$ in vitro}

In order to determine whether FrzA is secreted, we analyzed the production of FrzA by COS-7 cells transfected with a cDNA encoding myc-tagged bovine FrzA. After 3 days of culture, large amounts of FrzA protein were present in the conditioned medium (Fig. 8A), whereas the protein was virtually undetectable in the lysates of the transfected cells. These observations indicate that FrzA is an actively secreted protein.

We next wanted to test whether FrzA is able to bind Wnts. Because the majority of Wnts cannot be easily obtained as functionally active soluble proteins, we utilized culture supernatants of the S2-Wg cell line, which has been stably transfected with $w g$ cDNA under the control of a heat-shock promoter (van Leeuwen et al., 1994). In contrast to FrzA, Wg was mainly present in cell lysates (data not shown), with only a small proportion detected in the conditioned medium (Fig. $8 \mathrm{~B}$ ). Concentrated culture media containing $\mathrm{Wg}$ and myc-FrzA products were mixed in equal volumes, and myc-FrzA protein was precipitated with myc-specific 9E10 monoclonal antibodies. Subsequent western analysis with anti-Wg antibodies revealed the presence of $\mathrm{Wg}$ in the immune complexes (Fig. 8B,C, top panels). 9E10 antibodies reacted specifically with myc-FrzA and did not precipitate $\mathrm{Wg}$ from Wg-containing medium. The efficiency of myc-FrzA immunoprecipitation was verified by stripping the membrane and reprobing it with 9E10 antibodies (Fig. 8B,C, bottom panels). Conditioned media containing $\mathrm{Wg}$ and FrzA proteins

Fig. 8. Association of soluble FrzA and $\mathrm{Wg}$ proteins in vitro. (A) FrzA is actively secreted by transfected COS-7 cells. Subconfluent COS-7 cells were transfected with FrzA-pJ3 $\Omega$ M DNA or with $\mathrm{pJ} 3 \Omega \mathrm{M}$ vector DNA. The cells were allowed to condition the culture medium for 3 days, then the conditioned media and cell lysates were prepared and subjected to western analysis with antimyc 9E10 antibodies. Bottom panel: the same membrane was probed with a non-specific antibody to show equal loading. (B,C) Two experiments showing co-precipitation of $\mathrm{Wg}$ protein with FrzA from cell culture supernatants. Concentrated conditioned media containing $\mathrm{Wg}$ and FrzA proteins were mixed and FrzA was immunoprecipitated with 9E10 myc-specific antibodies as indicated. Rabbit anti-Wg antibodies were used to detect $\mathrm{Wg}$ in the immunoprecipitates by western analysis (top panels). To assess the efficiency of FrzA precipitation, the same membrane was stripped and reprobed with 9E10 antibodies (bottom panels). Control conditioned media from COS cells transfected with $\mathrm{pJ} 3 \Omega \mathrm{M}$ plasmid (C) or FrzA-pJ3 $\Omega \mathrm{M}$ (FrzA) and media from S2 and S2-Wg cells are analyzed by western blotting (right panels in B). The equivalent amounts of conditioned media before and after immunoprecipitation (IP) are compared in (C). Positions of specific bands corresponding to myc-FrzA and $\mathrm{Wg}$ proteins are indicated. Dark bands in left three lanes in B and C correspond to the heavy chains of 9E10 antibodies. revealed that FrzA was substantially depleted with 9E10 antibodies, but that the amount of $\mathrm{Wg}$ protein in the media did not significantly change (Fig. $8 \mathrm{C}$ ). These results indicate that while $\mathrm{Wg}$ associates with FrzA in vitro, only a small portion of $\mathrm{Wg}$ is present in complex with FrzA.

\section{DISCUSSION}

This study evaluates a potential role of a novel protein (FrzA), which is highly homologous to the extracellular domain of Frizzled receptors, in Wnt signal transduction. We demonstrate that FrzA is actively secreted into the culture medium, binds

A

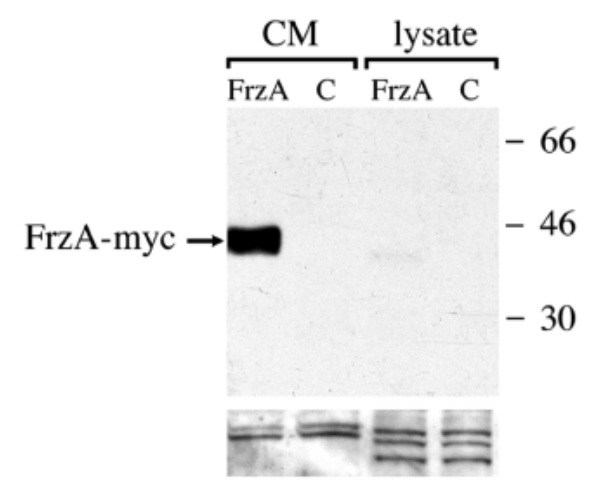

B

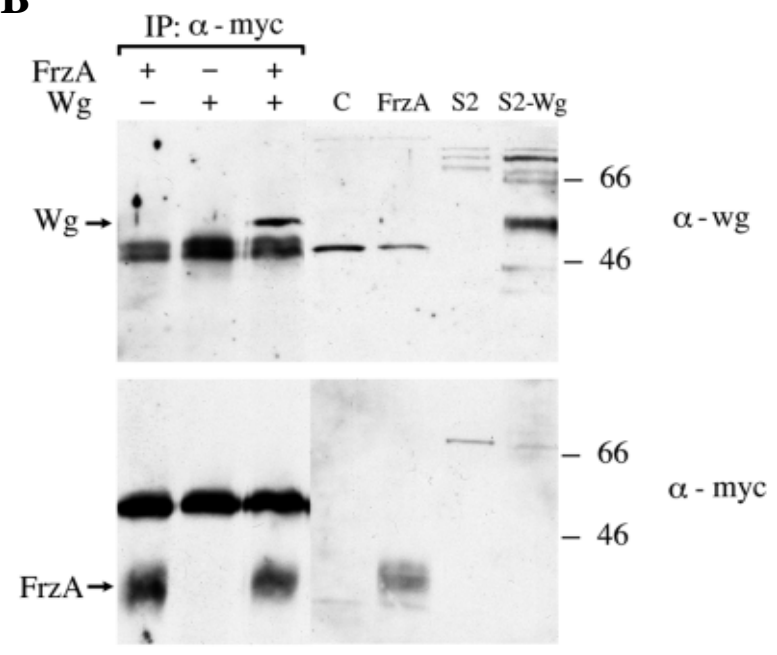

C
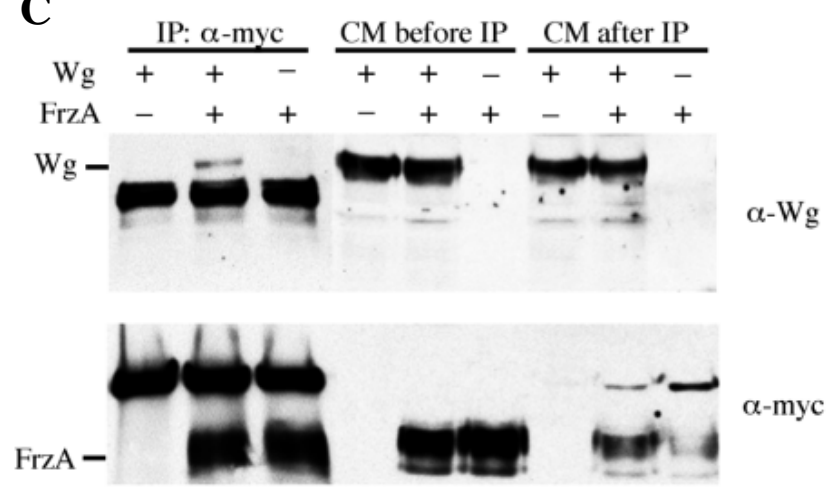
$\mathrm{Wg}$ in vitro and inhibits the activities of two Wnt products, Xwnt8 and human Wnt2 in the embryo. Developmental effects of FrzA are similar to the effect of a dominant negative Xdsh (Sokol, 1996), and are likely to reflect inhibition of Wnt signaling in the embryo.

Although recent reports have shown that $\mathrm{Wg}$ binds to the surface of cells transfected with Frizzled cDNAs (Bhanot et al., 1996), and that FrzB product binds to cells transfected with a membrane-bound form of Wnt-1 (Leyns et al., 1997), these findings do not demonstrate biochemical association of the two proteins. XfrzB was reported to associate with in vitro translated Xwnt8 product (Wang et al., 1997a), but the functional activity of the in vitro translated Xwnt8 was not demonstrated (Wang et al., 1997). Our data extend these observations by demonstrating that a soluble Wnt ligand $(\mathrm{Wg})$, which is secreted by cells in a biologically active form (Van Leeuwen et al., 1994), forms a biochemical complex with a secreted Frizzled-related protein (Fig. 8).

Other proteins related to the Frizzled CRD were identified recently (Shirozu et al., 1996; Rattner et al., 1997; Finch et al., 1997; Salic et al., 1997; Melkonyan et al., 1997), and two of them, SARP2 (Melkonyan et al., 1997) and FRP1 (Finch et al., 1997), are highly related to FrzA (Fig. 1). Among the best characterized Frizzled CRD-related proteins are FrzB homologues (Hoang et al., 1996; Mayr et al., 1997; Leyns et al., 1997; Wang et al., 1997a). FrzB transcripts are abundant in bovine cartilage (Hoang et al., 1996), mouse central and peripheral nervous system, and in the kidney (Mayr et al., 1997). In contrast, FrzA is found in adult cow brain, heart, kidney, spleen, lung and in some blood vessels (Duplaa et al., unpublished). In the early gastrulae, XfrzB transcripts are restricted to the organizer region (Leyns et al., 1997; Wang et al., 1997); however, XfrzA mRNA is not detectable at this time of development (Fig. 3). At tailbud stages, FrzB expression is confined to the stomodeal-hypophyseal anlage (Leyns et al., 1997; Wang et al., 1997), whereas FrzA is strongly expressed in the developing myocardium, otic vesicle, endoderm, pronephros and neural crest (Fig. 3). Thus, tissue distribution of FrzA and FrzB in Xenopus embryos suggest that these molecules may locally control Wnt activities, and that the specificity of their effects could be primarily determined by their expression patterns.

The existence of multiple Wnt ligands and their putative receptors and CRD-related proteins raises the question of whether there is any selectivity in these ligand-receptor interactions. To account for the observed synergy of Xwnt-5a and Hfz-5 in axis induction, Hfz-5 was proposed to function as a receptor for Xwnt-5a (He et al., 1997). With regards to soluble Frizzled CRD-related proteins, only FrzB has been reported to interact with Xwnt8 and Wnt1, but not with Wnt3A, -5A or -11 (Wang et al., 1997a,b; Leyns et al., 1997). Our experiments suggest that FrzA may interfere with the activities of at least three different Wnts, including Xwnt8, Wnt2 and $\mathrm{Wg}$, yet we failed to detect an effect of FrzA on the ability of Xwnt5a to block morphogenetic movements. FRP-1 inhibits functional activity of Xwnt8, but has only a weak effect on Xwnt-3a (He et al., 1997). While SARP-2 negatively regulates intracellular concentration of $\beta$-catenin, SARP- 1 leads to its upregulation, suggesting a stimulatory effect on the Wnt pathway (Melkonyan et al., 1997). Together, these observations suggest that different Frizzled CRD-related proteins may have diverse effects and different specificities in vivo. Further analysis requires purified preparations of various Wnts, which are not currently available.

Soluble binding proteins have been described for a number of different ligands. For example, a soluble receptor for vascular endothelial growth factor (VEGF) was shown to bind to the ligand and inhibit its biological activity (Kendall and Thomas, 1993). Soluble forms of the fibroblast growth factor (FGF) receptor have been identified in blood and are speculated to control FGF activities (Hanneken et al., 1994). The existence of membrane-anchored and soluble forms of growth factors and their receptors may reflect a common mechanism of controlling short- and long-range intercellular communications and establishing tissue boundaries in the embryo.

We thank R. Nusse for the S2-Wg cell line and for anti-Wg

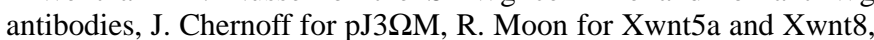
A. McMahon for human Wnt2, E. De Robertis for chordin, BMP-4 and XfrzB, R. Harland for Xnr3, M. Jamrich for PV1, J. Gurdon for XMyoD. We also thank K. Itoh and V. Krupnik for comments on the manuscript. This work was supported by the grants from the March of Dimes Birth Defects Foundation and NIH (HD31247) to S. Sokol and by the NIH grants EY05318 and CA45548 to P. D'Amore.

\section{REFERENCES}

Adler, P. N. (1992). The genetic control of tissue polarity in Drosophila. BioEssays 14, 735-741.

Ault, K. T., Dirksen, M.-L. and Jamrich, M. (1996). A novel homeobox gene PV.1 mediates induction of ventral mesoderm in Xenopus embryos. Proc. Nat. Acad. Sci. USA 93, 6415-6420.

Behrens, J., von Kries, J. P., Kühl, M., Bruhn, L., Wedlich, D., Grosschedl, R. and Birchmeier, W. (1996). Functional interaction of $\beta$-catenin with the transcription factor LEF-1. Nature 382, 638-642.

Bhanot, P., Brink, M., Samos, C. H., Hsieh, J.-C.,Wang, Y., Macke, J. P., Andrew, D., Nathans, J. and Nusse, R. (1996). A new member of the frizzled family from Drosophila functions as a Wingless receptor. Nature 382, 225-230

Blumberg, B., Wright, C. V. E., De Robertis, E. M. and Cho, K. W. Y. (1991). Organizer-specific homeobox genes in Xenopus laevis embryos. Science 253, 194-196.

Bouwmeester, T., Kim, S.-H., Sasai, Y., Lu, B., De Robertis, E. M. (1996). Cerebus is a head-inducing secreted factor expressed in the anterior endoderm of Spemann's organizer. Nature 382, 595-602.

Brunner, E., Peter, O., Schweizer, L. and Basler, K. (1997). Pangolin encodes a Lef-1 homologue that acts downstream of Armadillo to transduce the Wingless signal in Drosophila. Nature 385, 829-833.

Cadigan, K. M. and Nusse, R. (1997). Wnt signaling: a common theme in animal development. Genes Dev. 11, 3286-3305.

Chan, S. D. H., Karpf, D. B., Fowlkes, M. E., Hooks, M., Bradley, M. S., Vuong, V, Bambino, T., Liu, M. Y. C., Arnaud, C. D., Strewler, G. J. and Nisseson, R. A. (1992). Two homologs of the Drosophila polarity gene frizzled $(f z)$ are widely expressed in mammalian tissues. J. Biol. Chem. 267, 25202-25207.

Christian, J. L., McMahon, J. A., McMahon, A. P. and Moon, R. T. (1991). Xwnt8, a Xenopus Wnt-1/int-1-related gene responsive to mesoderminducing growth factors, may play a role in ventral mesodermal patterning during embryogenesis. Development 111, 1045-1055.

Christian, J. L. and Moon, R. T. (1993). Interactions between Xwnt-8 and spemann organizer signaling pathways generate dorsoventral pattern in the embryonic mesoderm of Xenopus. Genes Dev. 7, 13-28.

Dale, L., Howes, G., Price, B. M. J. and Smith, J. C. (1992). Bone morphogenetic protein 4: a ventralizing factor in early Xenopus development. Development 115, 573-585.

Dominguez, I., Itoh, K. and Sokol, S. Y. (1995). Role of glycogen synthase kinase $3 \beta$ as a negative regulator of dorsoventral axis formation in Xenopus embryos. Proc. Nat. Acad. Sci. USA 92, 8498-8502.

Du, S. J., Purcell, S. M., Christian, J. L., McGrew, L. L. and Moon, R. T. 
(1995). Identification of distinct classes and functional domains of Wnts through expression of wild-type and chimeric proteins in Xenopus embryos. Mol. Cell. Biol. 15, 2625-2634.

Evan, G. I., Lewis, G. K., Ramsay, G. and Bishop, J. M. (1985). Isolation of monoclonal antibodies specific for human c-myc proto-oncogene product. Mol. Cell. Biol. 5, 3610-3616.

Finch, P. W., He, X., Kelley, M. J., Uren, A., Schaudies, R. P., Popescu, N. C., Rudikoff, S., Aaronson, S. A., Varmus, H. E. and Rubin, J. S. (1997) Purification and molecular cloning of a secreted, Frizzled-related antagonist of Wnt action. Proc. Nat. Acad. Sci. USA 94, 6770-6775.

Fredieu, J. R., Cui, Y., Maier, D., Danilchik, M. V. and Christian, J. L. (1997). Xwnt-8 and lithium can act upon either dorsal mesodermal or neuroectodermal cells to cause a loss of forebrain in Xenopus embryos. Dev. Biol. 186, 100-114.

Funayama, N., Fagotto, F., McCrea, P. and Gumbiner, B. M. (1995). Embryonic axis induction by the Armadillo repeat domain of $\beta$-catenin: evidence for intracellular signalling. J. Cell Biol. 128, 959-968.

Graham, F. L. and Van Der Eb, A. J. (1973). A new technique for the assay of infectivity of human adenovirus 5 DNA. Virology 52, 456-467

Hanneken, A., Ying, W., Ling, N. and Baird, A. (1994). Identification of soluble forms of the fibroblast growth factor receptor in blood. Proc. Nat. Acad. Sci USA 91, 9170-9174.

Harland, R. M. (1991). In situ hybridization: an improved whole-mount method for Xenopus embryos. Methods Cell Biol. 36, 685-695.

He, X., Saint-Jeannet, J.-P., Woodgett, J. R., Varmus, H. E. and Dawid, I. B. (1995). Glycogen synthase kinase-3 and dorsoventral patterning in Xenopus embryos. Nature 374, 617-622.

He, X., Saint-Jeannet, J.-P., Wang, Y., Nathans, J., Dawid, I. and Varmus, H. (1997). A member of the Frizzled protein family mediating axis induction by Wnt-5A. Science 275, 1652-1654.

Heasman, J., Crawford, A., Goldstone, K., Garner-Hamrick, P., Gumbiner, B., McCrea, P., Kintner, C., Yoshida Noro, C. and Wylie, C. (1994). Overexpression of cadherins and underexpression of $\beta$-catenin inhibit dorsal mesoderm induction in early Xenopus embryos. Cell 79, 791803.

Herzlinger, D., Qiao, J., Cohen, D., Ramakrishna, N., Brown, A. M. C. (1994). Induction of kidney epithelial morphogenesis by cells expressing Wnt-1. Dev. Biol. 166, 815-818.

Hoang, B., Moos, M., Jr., Vukicevic, S. and Luyten, F. P. (1996). Primary structure and tissue distribution of FRZB, a novel protein related to Drosophila frizzled, suggest a role in skeletal morphogenesis. J. Biol. Chem. 271, 26131-26137.

Hoppler, S., Brown, J. D. and Moon, R. T. (1996). Expression of a dominant negative Wnt blocks induction of MyoD in Xenopus embryos. Genes Dev. 10, $2805-2817$

Hopwood, N. D., Pluck, A. and Gurdon, J. B. (1989). MyoD expression in the forming somites is an early response to mesoderm induction in Xenopus embryos. EMBO J. 8, 3409-3417.

Huber, O., Korn, R., McLaughlin, J., Ohsugi, M., Herrmann, B. G. and Kemler, R. (1996). Nuclear localization of beta-catenin by interaction with transcription factor LEF-1. Mech. Dev. 59, 3-10.

Itoh, K., Tang, T. L., Neel, B. G and Sokol, S. Y. (1995). Specific modulation of ectodermal cell fates in Xenopus embryos by glycogen synthase kinase. Development 121, 3979-3988.

Itoh, K. and Sokol, S. Y. (1997). Graded amounts of Xenopus dishevelled specify discrete anteroposterior cell fates in prospective ectoderm. Mech. Dev. 61, 113-125.

Karnovsky, A. and Klymkowsky, M. W. (1995). Anterior axis duplication in Xenopus induced by the over-expression of the cadherin-binding protein plakoglobin. Proc. Nat. Acad. Sci. USA 92, 4522-4526.

Kendall, R. L. and Thomas, K. A. (1993). Inhibition of vascular endothelial growth factor activity by an endogenously encoded soluble receptor. Proc. Nat. Acad. Sci. USA 90, 10705-10709.

Krieg, P. A. and Melton, D. A. (1984). Functional messenger RNAs are produced by SP6 in vitro transcription of cloned cDNAs. Nucl. Acids Res. 12, 7057-7070.

Krieg, P. A and Melton, D. A. (1985). Developmental regulation of a gastrula specific gene injected into fertilized Xenopus eggs. EMBO J. 4, 3463-3471.

Leyns, L., Bouwmeester, T., Kim, S.-H., Piccolo, S. and De Robertis, E. M. (1997). Frzb-1 is a secreted antagonist of Wnt signaling expressed in the Spemann organizer. Cell 88, 757-766.

Mayr, T., Deutsch, U., Kuhl, M., Drexler, H. C. A., Lottspeich, F., Deutzmann, R., Wedlich, D. and Risau, W. (1997). Fritz: a secreted frizzled-related protein that inhibits Wnt activity. Mech. Dev. 63, 109-125.
McGrew, L. L., Lai, C.-J. and Moon, R. T. (1995). Specification of the anteroposterior neural axis through synergistic interaction of the Wnt signalling cascade with noggin and follistatin. Dev. Biol. 172, 337-342.

Melkonyan, H. S., Chang, W. C., Shapiro, J. P., Mahadevappa, M., Fitzpatrick, P. A., Kiefer, M. C., Tomei, L. D. and Umansky, S. R. (1997) SARPs: a family of secreted apoptosis-related proteins. Proc. Nat. Acad. Sci. USA 94, 13636-13641.

Molenaar, M., van de Wetering, M., Oosterwegel, M., Peterson-Maduro, J., Godsave, S., Korinek, V., Roose, J., Destrée, O. and Clevers, H. (1996). XTcf-3 transcription factor mediates $\beta$-catenin-induced axis formation in Xenopus embryos. Cell 86, 391-399.

Moon, R. T., Campbell, R. M., Christian, J. L., McGrew, L., Shih, J. and Fraser, S. (1993). Xwnt-5A: a maternal Wnt that affects morphogenetic movements after overexpression in embryos of Xenopus laevis. Development 119, 97-111.

Newport, J. and Kirschner, M. (1982). A major developmental transition in early Xenopus embryos: I. Characterization and timing of cellular changes at the midblastula stage. Cell 30, 675-686.

Nieuwkoop, P. D. and Faber, J. (1967). Normal Table of Xenopus laevis (Daudin). North Holland Publ., Amsterdam, Holland.

Pannese, M., Polo, C., Andreazzoli, M., Vignali, R., Kablar, B., Barsacchi, G. and Boncinelli, E. (1995). The Xenopus homologue of Otx2 is a maternal homeobox gene that demarcates and specifies anterior body regions. Development 121, 707-720.

Parr, B. A. and McMahon, A. P. (1994). Wht genes and vertebrate development. Curr. Opin. Genet. Dev. 4, 523-528.

Parr, B. A. and McMahon, A. P. (1995). Dorsalizing signal Wnt-7a required for normal polarity of D-V and A-P axes in mouse limb. Nature 374, 350353.

Patriotis, C., Makris, A., Chernoff, J. and Tsichlis, P. N. (1994). Tpl-2 acts in concert with Ras and Raf-1 to activate mitogen-activated protein kinase. Proc. Nat. Acad. Sci. USA 91, 9755-9759.

Perrimon, N. (1994). The genetic basis of patterned baldness in Drosophila. Cell 76, 781-784.

Perrimon, N. (1996). Serpentine proteins slither into the wingless and hedgehog fields. Cell 86, 513-516.

Pierce, S. B. and Kimelman, D. (1995). Regulation of Spemann organizer formation by the intracellular kinase Xgsk-3. Development 121, 755765

Rattner, A., Hsieh, J. C., Smallwood, P. M., Gilbert, D. J., Copeland, N. G., Jenkins, N. A. and Nathans, J. (1997). A family of secreted proteins contains homology to the cysteine-rich ligand-binding domain of frizzled receptors. Proc. Nat. Acad. Sci. USA 94, 2859-2863.

Riddle, R. D., Ensini, M., Nelson, C., Tsuchida, T., Jessell, T. M. and Tabin, C. (1995). Induction of the LIM homeobox gene Lmxl by WNT7a establishes dorsoventral pattern in the vertebrate limb. Cell $\mathbf{8 3}$ 631-640.

Rocheleau, C. E., Downs, W. D., Lin, R., Wittmann, C., Bei, Y., Cha, Y.H., Ali, M., Priess, J. R. and Mello, C. C. (1997). Wnt signaling and an APC-related gene specify endoderm in early C. elegans embryos. Cell $\mathbf{9 0}$, 707-716.

Rothbacher, U., Laurent, M. N., Blitz, I. L., Watabe, T., Marsh, J. L and Cho, K. W. Y. (1995). Functional conservation of the Wnt signaling pathway revealed by ectopic expression of Drosophila dishevelled in Xenopus. Dev. Biol. 170, 717-721.

Salic, A. N., Kroll, K. L., Evans, L. M. and Kirschner, M. W. (1997) Sizzled: a secreted Xwnt8 antagonist expressed in the ventral marginal zone of Xenopus embryos. Development 124, 4739-4748.

Sambrook, J., Fritsch, E. F. and Maniatis, T. (1989). Molecular Cloning: A Laboratory Manual. Cold Spring Harbor Laboratory Press, Cold Spring Harbor, New York.

Sasai, Y., Lu, B., Steinbeisser, H., Geissert, D., Gont, L. K. and De Robertis, E. M. (1994). Xenopus chordin: A novel dorsalizing factor activated by organizer-specific homeobox genes. Cell 79, 779-790.

Sasai, Y., Lu, B., Steinbeisser, H. and De Robertis, E. M. (1995). Regulation of neural induction by the Chd and Bmp-4 antagonistic patterning signals in Xenopus. Nature 376, 333-336.

Shirozu, M., Tada, H., Tashiro, K., Nakamura, T., Lopez, N. D., Nazarea, M., Hamada, T., Sato, T., Nakano, T. and Honjo, T. (1996). Characterization of novel secreted and membrane proteins isolated by the signal sequence trap method. Genomics 37, 273-280.

Smith, W. C. and Harland, R. M. (1991). Injected Xwnt-8 RNA acts early in Xenopus embryos to promote formation of a vegetal dorsalizing center Cell 67, 753-765. 
Smith, J. C., Price, B. M. J., Green, J. B. A., Weigel, D. and Herrmann, B. G. (1991). Expression of a Xenopus homologue of brachyury $(T)$ is an immediate-early response to mesoderm induction. Cell 67, 79-87.

Smith, W. C., McKendry, R., Ribisi, S., Jr. and Harland, R. M. (1995). A nodal-related gene defines a physical and functional domain within the Spemann organizer. Cell 82, 37-46.

Sokol, S. Y. (1993). Mesoderm formation in Xenopus ectodermal explants overexpressing Xwnt8: evidence for a cooperating signal reaching the animal pole by gastrulation. Development 118, 1335-1342.

Sokol, S. (1996). Analysis of Dishevelled signalling pathways during Xenopus development. Curr. Biol. 6, 1456-1467.

Sokol, S., Christian, J. L., Moon, R. T. and Melton, D. A. (1991). Injected Wnt RNA induces a complete body axis in Xenopus embryos. Cell 67, 741752 .

Sokol, S. Y., Klingensmith, J., Perrimon, N. and Itoh, K. (1995). Dorsalizing and neuralizing properties of Xdsh, a maternally expressed Xenopus homologue of dishevelled. Development 121, 1637-1647.

Stark, K., Vainio, S., Vassileva, G. and McMahon, A. P. (1994). Epithelial transformation of metanephric mesenchyme in the developing kidney regulated by Wnt-4. Nature 372, 679-683.

Taira, M., Jamrich, M., Good, P. J. and Dawid, I. B. (1992). The LIM domain-containing homeobox gene Xlim-1 is expressed specifically in the organizer region of Xenopus gastrula embryos. Genes Dev. 6, 356-366.

Thorpe, C. J., Schlesinger, A., Carter, J. C. and Bowerman, B. (1997). Wnt signaling polarizes an early $C$. elegans blastomere to distinguish endoderm from mesoderm. Cell 90, 695-705.

van Leeuwen, F., Samos, C. H. and Nusse, R. (1994). Biological activity of soluble wingless protein in cultured Drosophila imaginal discs cells. Nature 368, 342-344.

van de Wetering, M., Cavallo, R., Dooijes, D., van Beest, M., van Es, J., Loureiro, J., Ypma, A., Hursh, D., Jones, T., Bejsovec, A., Peifer, M., Mortin, M. and Clevers, H. (1997). Armadillo co-activates transcription driven by the product of the Drosophila segment polarity gene dTCF. Cell 88, 789-799.

Vinson, C. R., Conover, S. and Adler, P. N. (1989). A Drosophila tissue polarity locus encodes a protein containing seven potential transmembrane domains. Nature 338, 263-264.

Wang, Y., Macke, J. P., Abella, B. S., Andreasson, K., Worley, P., Gilbert, D. J., Copeland, N. G., Jenkins, N. A. and Nathans, J. (1996). A large family of putative transmembrane receptors homologous to the product of the Drosophila tissue polarity gene frizzled. J. Biol. Chem. 271, 44684476.

Wang, S., Krinks, M., Lin, K., Luyten, F. P. and Moos, Jr., M. (1997a). Frzb, a secreted protein expressed in the Spemann organizer, binds and inhibits Wnt-8. Cell 88, 757-766.

Wang, S., Krinks, M. and Moos, Jr., M. (1997b). Frzb-1, an antagonist of Wnt-1 and Wnt-8, does not block signaling by Wnts-3A, $-5 \mathrm{~A}$, or -11 . Biochem. Biophys. Res. Comm. 236, 502-504.

Wolda, S. L., Moody, C. J. and Moon, R. T. (1993). Overlapping expression of Xwnt-3A and Xwnt-1 in neural tissue of Xenopus laevis embryos. Dev. Biol. 155, 46-57.

Yanagawa, S., van Leeuwen, F., Wodarz, A., Klingensmith, J. and Nusse, R. (1995). The Dishevelled protein is modified by Wingless signalling in Drosophila. Genes Dev. 9, 1087-1097.

Yang, Y. and Niswander, L. (1995). Interaction between the signalling molecules WNT7A and SHH during vertebrate limb development: dorsal signals regulate anteroposterior patterning. Cell 80, 939-947.

Yang-Snyder, J., Miller, J. R., Brown, J. D., Lai, C.-J. and Moon, R. T. (1996). A frizzled homolog functions in a vertebrate Wnt signaling pathway. Curr. Biol. 6, 1302-1306.

Zeng, L., Fagotto, F., Zhang, T., Hsu, W., Vasicek, T. J., Perry III, W. L., Lee, J. J., Tilghman, S. M., Gumbiner, B. M. and Costantini, F. (1997). The mouse Fused locus encodes Axin, an inhibitor of the Wnt signaling pathway that regulates embryonic axis formation. Cell 90, 181-192. 